\title{
Efek Pemberian Ekstrak Buah Kersen (Muntingia Calabura) terhadap Histopatologi Paru Tikus yang Dipapar Asap Rokok
}

\section{Effect of Kersen Fruit Extract (Muntingia Calabura) on the Histopathology of Rat Lungs Exposed to Cigarette Smoke}

\author{
Ika Dyah Kurniati ${ }^{11}$, Dyah Mustika Nugraheni ${ }^{1)}$ \\ 1)Bagian Biomedik, Fakultas Kedokteran, Universitas Muhammadiyah Semarang \\ Fakultas Kedokteran Universitas Muhammadiyah Semarang \\ Jalan Kedungmundu Raya No.18 Semarang. Email: ika@unimus.ac.id
}

\begin{abstract}
Abstrak
Latar belakang : Oksidan yang terkandung dalam asap rokok dapat menyebabkan terjadinya stres oksidatif. Buah kersen (Muntingia calabura) mengandung antioksidan diantaranya flavonoid. Penelitian ini bertujuan mengetahui efek proteksi ekstrak buah kersen terhadap kerusakan histologis alveolus paru tikus Sprague dawley yang terpapar asap rokok

Metode : Tikus sejumlah dibagi 4 kelompok, kemudian di papar asap rokok 7 batang perhari dan ekstrak buah kersen (EBK) selama 4 minggu. Kelompok pertama sebagai kontrol (K1) diberi plasebo, kelompok kedua (K2) dipapar asap rokok saja, sedangkan sisanya merupakan kelompok Perlakuan 1 (P1) diberi EBK 100mg/kgBB/hari dan Perlakuan 2 (P2) diberi EBK $200 \mathrm{mg} / \mathrm{kgBB} /$ hari. Perbedaan derajat kerusakan alveolus di analisis dengan Kruskal-Wallis Test.

Hasil : Rerata derajat kerusakan alveolus pada kelompok kontrol (K1)sejumlah $(69,44)$ kelompok perlakuan 1 (P1) sejumlah $(80,00)$ dan kelompok perlakuan 2 (P2) sejumlah $(79,63)$ sedangkan yang terendah yaitu pada kelompok kontrol paparan asap rokok (K2) sejumlah $(61,11)$. Nilai $P=0.464$, menunjukkan bahwa tidak terdapat perbedaaan yang bermakna derajat kerusakan alveolus antar kelompok, dimana rerata derajat kerusakan alveolus paru $>60 \%$ (kerusakan berat).
\end{abstract}

Simpulan : Pemberian ekstrak buah kersen tidak berpengaruh terhadap gambaran mikroskopis paru tikus yang di papar asap rokok.

Kata kunci : asap rokok, buah kersen, kerusakan histologi alveolus paru

\section{Abstract}

Background: Oxidant which is contain in cigarette smoke increases oxidative stress. Kersen fruit (Muntingia calabura) contains antioxidants including flavonoids. The purpose of this study is to proves protecting effect of kersen fruit extract on the lung tissue.

Method: Rats were divided into 4 groups that had been exposed 7 cigarrete smoke a day and given kersen fruit extract (KFE) for 4 weeks. The first group as the control group (K) was given a placebo, second group were exposed cigarrete smoke only, treatment group 1 (T1) and treatment group 2 (T2) were treated with 100 and $200 \mathrm{mg} / \mathrm{kgBodyWeight} /$ day KFE, respectively. The difference in the degree of alveolar damages were analyzed.

Results: There were no significant differences in the degree of alveolar damages between groups. The average degree of alveolar damages was severe, where the alveolar damages were $>60 \%$.

Conclusion: Kersen fruit has no effect on the histopathology of alveolar damage

Keywords: cigarette smoke, kersen fruit, alveolar damages 


\section{Latar Belakang}

PPOK (Penyakit Paru Obstruksi

oksidatif dengan mengaktifkan makrofag alveolus untuk melepaskan sitokin antara lain LB4, IL-8 dan TNF- $\alpha .{ }^{5-8}$

Kronis) merupakan salah satu masalah Untuk mencegah dampak buruk kesehatan di dunia, dimana prevalensinya yang tinggi memberikan dampak sosial ekonomi yang buruk. PPOK saat ini merupakan penyebab kematian no. 4 di dunia, dan kemungkinan akan meningkat untuk menetralisir antara lain SOD menjadi no 3 pada tahun 2020.1,2 PPOK (superoksid dismutase), dari luar antara lain dapat disebabkan antara lain oleh polusi dari makanan dimana mengandung zat udara dan asap rokok. 2,3,4 Menurut data antioksidan yang digunakan sebagai pemutus WHO, Indonesia merupakan negara ketiga rantai (chain-breaking antioxidant) yaitu vitamin setelah Cina dan India yang memiliki jumlah C, vitamin E, beta karoten, dan golongan perokok aktif terbanyak di dunia yaitu flavonoid. 9,10

sebesar 61,4 juta perokok. Perilaku merokok Buah kersen (Muntingia calabura penduduk Indonesia cenderung meningkat Linn) adalah buah yang banyak tumbuh di dari $34,2 \%$ pada tahun 2007 menjadi 36,3\% Indonesia, namun masyarakat belum banyak pada tahun $2013 .^{1}$

mengetahui manfaat dari buah kersen dan

Dalam setiap hisapan rokok, menyebabkan banyaknya buah kersen yang terdapat $10^{14}$ radikal bebas dan dapat tidak digunakan manfaatkan terutama dipertahankan dalam waktu yang relatif lama dibidang kesehatan. Buah kersen (Muntingia $(>10$ menit). Asap rokok tersebut calabura Linn) memiliki aktivitas antioksidan merupakan oksidan yang dapat yang kuat karena kandungan asam askorbat menghilangkan antioksidan intraseluler (vitamin C) yang tinggi, vitamin A dan juga dalam sel paru-paru dan berhubungan mineral seperti kalsium dan fosfor. dengan mekanisme peningkatan stres Kandungan vitamin $\mathrm{C}$ buah kersen 
(379,75mg) 3x lipat dari buah mengkudu (175mg). Dosis lethal ekstrak buah kersen adalah 1000mg/kg. Hasil ekstrak polifenol buah kersen menunjukkan bahwa buah kersen mengandung antioksidan antara lain vitamin C (33,6mg AAE/g ekstrak), vitamin E $(14,7 \mathrm{mg}$ TE/g ekstrak), total fenol (121,1mg GAE/g ekstrak), flavonoid (173,2mg RE/g ekstrak) dan antosianin $\left(82,4 \mathrm{mg}\right.$ CGE/g ekstrak). ${ }^{11}$

Buah kersen merupakan salah satu sumber antioksidan alami yang mudah dibudidayakan di Indonesia. Kandungan antioksidan pada buah kersen, diharapkan Sprague-Dawley. Kriteria inklusi adalah umur dapat menurunkan jumlah oksidan yang 2-3 bulan, berat 150-200 gram, sehat. disebabkan paparan asap rokok yang Kriteria eklusi adalah tikus tidak bergerak terhirup oleh paru-paru. Penelitian ini aktif, terdapat abnormalitas anatomi yang bertujuan untuk mengetahui efek proteksi tampak. Kriteria drop out adalah tikus mati. ekstrak buah kersen terhadap kerusakan Besar sampel ditentukan berdasarkan rumus histologis alveolus paru tikus Sprague dawley $\mathrm{WHO}^{12}$ jumlah sampel setiap kelompok yang di papar asap rokok.

\section{Metode}

Penelitian ini merupakan penelitian eksperimental laboratorik dengan rancangan Post Test Only Control Group Desain. Penelitian ini telah mendapatkan persetujuan dari komisi etik Fakultas Kedokteran Universitas Diponegoro Semarang. Tempat penelitian dilakukan di di Laboratorium Unit Pangan dan Gizi Pusat Antar Universitas (PAU) Universitas Gajah Mada (UGM), Laboratorium Patologi Anatomi FK UGMRS Sardjito Yogyakarta dan Laboratorium Patologi Anatomi FK UNDIP Semarang periode Agustus-Oktober 2016.

\section{Subjek Penelitian}

Hewan coba yang dipakai pada penelitian ini adalah tikus putih jantan galur perlakuan minimal 5 ekor tikus tiap kelompok. Antisipasi drop out dilakukan dengan menambahkan 1 tikus pada masingmasing kelompok.

Pembuatan Ekstrak metanol buah kersen (Muntingia calabura)

Vol. 1 No.5 Agustus 2018 
Buah kersen segar di blender 7 batang per hari. Kelompok ketiga sebagai

kemudian diekstrak menggunakan metanol dengan perbandingan 1:3 (jus buah : pelarut) menggunakan orbital shaker pada suhu ruang, kemudian ekstrak di sentrifuge dan supernatan dikumpulkan. Untuk mendapatkan maserat digunakan rotary evaporator pada suhu $40^{\circ} \mathrm{C}$ dilanjutkan dengan diuapkan dengan nitrogen sehingga didapatkan ekstrak buah kersen yang kental dan konsentrasinya kersen dilakukan selama 4 minggu. mendekati $99 \%$. Dosis ekstrak buah kersen 4 Setelah 4 minggu perlakuan, tikus di yang dibuat adalah $100 \mathrm{mg} / \mathrm{kg} \mathrm{BB}$ dan 200 terminasi dan diambil jaringan paru $\mathrm{mg} / \mathrm{kg}$ yang dilarutkan dalam $\mathrm{Na}$ CMC $0,5 \%$ kemudian dilakukan pemrosesan jaringan $2 \mathrm{ml} / 200 \mathrm{gr} \mathrm{BB}$.

\section{Protokol Penelitian}

Sampel tikus Sprague-Dawley jantan

dibagi menjadi 4 kelompok secara random. Kelompok pertama sebagai kontrol $(\mathrm{K})$ yang diberikan placebo ( $\mathrm{Na}$ CMC 0,5\%) dan paparan asap rokok kretek tanpa filter 7 batang per hari. Kelompok perlakuan satu (P1) yang diberikan ekstrak buah kersen melalui sonde lambung dengan dosis 100 $\mathrm{mg} / \mathrm{kg} \mathrm{BB}$ yang dilarutkan dalam $\mathrm{Na}$ CMC 0,5\% 2ml/200gr BB dan paparan asap rokok dan pengecatan $\mathrm{HE}$ sesuai standar pemeriksaan histopatologi di Laboratorium

perlakuan dua (P2) yang diberikan ekstrak buah kersen melalui sonde lambung dengan dosis $200 \mathrm{mg} / \mathrm{kg} \mathrm{BB}$ yang dilarutkan dalam $\mathrm{Na}$ CMC 0,5\% 2ml/200gr BB dan paparan asap rokok 7 batang per hari. Pemberian ekstrak buah kersen diberikan 30 menit sebelum pemaparan asap rokok. Paparan asap rokok dan pemberian ekstrak buah Patologi Anatomi FK UGM.

\section{Penilaian Derajat Kerusakan Alveolus} Paru

Penilaian derajat kerusakan alveolus paru dilakukan oleh Ahli Patologi Anatomi, dengan kriteria penilaian sebagaimana pada tabel 1. Setiap preparat jaringan paru diamati gambaran mikroskopisnya dengan perbesaran 400 kali pada 5 lapang pandang secara acak. 
Tabel 1. Kriteria Penilaian Derajat Kerusakan Alveolus Paru (Hansel dan Barnes) ${ }^{13}$

\begin{tabular}{l|l|l}
\hline Kriteria & Keterangan & $\begin{array}{l}\text { Nilai } \\
\text { Variasi }\end{array}$ \\
\hline Normal & Tidak terjadi perubahan histologis & 0 \\
\hline Kerusakan Ringan & $\begin{array}{l}\text { Kerusakan alveolus paru } \square 0 \% \text { sampai } \square 30 \% \text { dari } \\
\text { kerusakan maksimal }\end{array}$ & 1 \\
\hline Kerusakan Sedang & $\begin{array}{l}\text { Kerusakan alveolus paru 30\%-60\% dari kerusakan } \\
\text { maksimal }\end{array}$ & 2 \\
\hline Kerusakan Berat & $\begin{array}{l}\text { Kerusakan alveolus paru } \square 60 \% \text { kerusakan } \\
\text { maksimal }\end{array}$ & 3 \\
\hline
\end{tabular}

\section{Analisa Statistika}

Data yang diperoleh diolah dengan program komputer SPSS. Data di uji normalitas data menggunakan uji One-Sample Kolmogorov-Smirnov Test. Oleh karena distribusi data tidak normal sehingga digunakan uji beda menggunakan uji statistik Grafik 1. Data Deskriptif Rerata Kerusakan Alveolus pada sampel parametrik Kruskal-Wallis Test. penelitian

Data tersebut menunjukkan bahwa rerata derajad kerusakan alveolus pada kelompok Hasil kontrol sehat sejumlah $(69,44)$ kelompok Hasil Penelitian perlakuan 1 (P1) sejumlah $(80,00)$ dan Hasil pembacaan dan perhitungan kelompok perlakuan 2 (P2) sejumlah $(79,63)$ derajat kerusakan alveolus paru meliputi sedangkan yang terendah yaitu pada destruksi septum alveolar, edema paru, dan kelompok kontrol paparan asap rokok $(\mathrm{K})$ infiltrasi sel radang dengan hasil seperti pada sejumlah $(61,11)$. Hasil uji normalitas data Grafik 1.

terhadap variabel penelitian dengan SaphiroWilk Test Test bernilai $P=0,012$ dimana $\mathrm{p}<$ 0,05 yang berarti bahwa data variabelvariabel penelitian tersebut tidak terdistribusi normal sehingga dilakukan analisis statistik Kruskal-Wallis Test. 
Hasil analisa statistik dengan Kruskal-Wallis Test didapatkan nilai $P=$ 0.464. Hal ini menunjukkan bahwa tidak terdapat perbedaaan yang bermakna derajat kerusakan alveolus pada tiap kelompok, baik kelompok sehat, kelompok yang dipapar asap rokok tanpa diberikan ekstrak buah kersen serta kelompok yang diberikan ekstrak buah kersen baik dosis 100 mg / kgBB / hari maupun 200 mg / kgBB / hari.

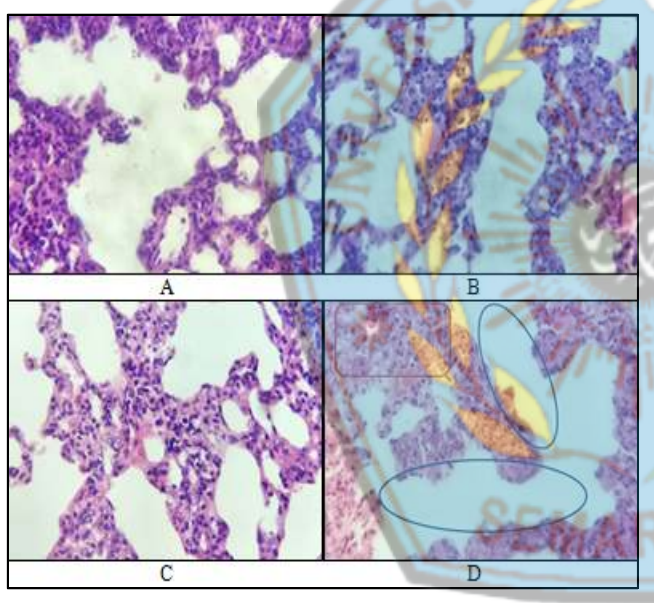

Gambar 4.1. Gambaran histopatologi paru pada keempat kelompok, yaitu kelompok kontrol sehat (gambar A), kelompok control negatif (gambar B) kelompok perlakuan 1 (gambar C), dan kelompok perlakuan 2 (gambar D), (pembesaran 400x).

A. Kelompok Kontrol sehat : Radang 70\%, Edema 60\%, Destruksi 50\%

B. Kelompok Kontrol negatif : Radang 60\%, Edema 30\%, Destruksi 40\%

C. Kelompok Perlakuan 1, EBK dosis 100 $\mathrm{mg} / \mathrm{kg} \mathrm{BB}$ ): Radang 50\%, Edema 50\%, Destruksi 60\%

D. Kelompok Perlakuan 2, EBK dosis 200 $\mathrm{mg} / \mathrm{kg} \mathrm{BB}$ ): Radang 70\% (kotak merah dan area lain yang serupa), Edema $70 \%$ (area dalam kotak merah dan area lain yang serupa), Destruksi 80\% (lingkaran biru)

\section{Diskusi}

Studi ini menunjukkan bahwa tidak terdapat perbedaaan yang bermakna derajat kerusakan alveolus pada tiap kelompok, baik kelompok sehat, kelompok yang dipapar asap rokok tanpa diberikan ekstrak buah kersen serta kelompok yang diberikan ekstrak buah kersen baik dosis $100 \mathrm{mg} /$ $\mathrm{kgBB}$ / hari mapun $200 \mathrm{mg} / \mathrm{kgBB}$ / hari. Rerata derajat kerusakan alveolus pada kelompok kontrol sehat sejumlah $(69,44)$ kelompok perlakuan 1 (P1) sejumlah $(80,00)$ dan kelompok perlakuan 2 (P2) sejumlah $(79,63)$ sedangkan yang terendah yaitu pada kelompok kontrol paparan asap rokok $(\mathrm{K})$ sejumlah (61,11). Walaupun terdapat perbedaan pada tiap kelompok namun berdasarkan kriteria penilaian derajat kerusakan alveolus paru, derajat pada semua kelompok termasuk dalam kriteria berat, dimana kerusakan alveolus paru $>60 \%$ kerusakan maksimal.

Nilai skor perubahan struktur histopatologi paru semakin meningkat sesuai 
dengan dosis ekstrak yang diberikan. Hal ini yang diinduksi hepatotoksik mampu sesuai dengan teori hubungan konsentrasi meningkatkan kadar antioksidan enzimatis dan respon, yaitu semakin tinggi konsentrasi, pada jaringan hepar secara signifikan antara semakin besar pula respon yang timbul lain SOD, CAT dan Glutathione peroxidase (respon terapi dan respon toksik), sehingga (GPx). Selain itu juga didapatkan penurunan pada rentang dosis tertentu, konsentrasi obat kadar vitamin E dan C yang signifikan pada reseptor tidak hanya menimbulkan efek setelah pemberian ekstrak buah kersen. Hal terapi, tetapi dapat juga menimbulkan efek ini membuktikan bahwa efek toksik. ${ }^{14}$ Perubahan struktur histopatologi hepatoprotektif terjadi karena kemampuan yang terjadi pada paru ini menunjukkan ekstrak buah kersen untuk memblokir bahwa pendapat masyarakat tentang obat bioaktivasi dari toksin dan merupakan alternatif yang tidak memiliki efek samping, antioksidan yang poten dalam menangkap aman dan praktis adalah kurang tepat, oleh radikal bebas dan menghambat peroksidasi karena itu, masyarakat diharapkan lebih lipid. Vitamin C dan vitamin E mampu waspada dan hati-hati dalam mengkonsumsi bertindak sebagai scavenger radikal bebas yang ekstrak buah kersen. Dalam penelitian ini penting yang mampu digunakan sebagai terdapat keterbatasan yang dipengaruhi oleh pemutus rantai (chain-breaking antioxidant) di adanya faktor-faktor seperti tingkat dosis, membran. Vitamin E mengurangi jumlah sampel dan waktu yang terbatas. hidroperoksida lipid yang dihasilkan selama Buah kersen mengandung proses peroksidasi dan melindungi struktur antioksidan antara lain vitamin C, vitamin E, sel terhadap kerusakan sel. ${ }^{15}$

fenol, flavonoid dan antosianin. ${ }^{11} \quad$ Kandungan antioksidan lain pada Komponen antioksidan seperti asam fenol, buah kersen yaitu flavonoid, yang memiliki polifenil dan flavonoid mampu memangsa aktivitas antiinflamasi, antialergi, anti-virus, radikal bebas dan menghambat mekanisme dan anti-karsinogenik. Salah satu mekanisme oksidatif. Pemberian ekstrak methanol buah yang dapat digunakan untuk menjelaskan kersen dosis $200 \mathrm{mg} / \mathrm{kgBB} /$ hari pada tikus hubungan antara aktivitas anti-inflamasi dan 
anti-oksidan adalah reaksi yang disebabkan oleh ROS. ROS yang merupakan jenis stimulus inflamasi, yang menyebabkan pelepasan oksida nitrat (NO). Hal tersebut menunjukkan bahwa pemblokiran ROS akan menyebabkan penurunan sintesis $\mathrm{NO}$, yang pada gilirannya akan mengarah pada aktivitas anti-inflamasi, anti kanker dan antioksidan. ${ }^{16}$

\section{Walaupun beberapa literatur}

menyatakan bahwa ekstrak buah kersen mengandung antioksidan, namun studi ini menunjukkan bahwa pemberian ekstrak buah kersen tidak berpengaruh terhadap gambaran mikroskopis paru tikus yang di papar asap rokok. Walaupun terdapat perbedaan pada tiap kelompok namun berdasarkan kriteria penilaian derajat kerusakan alveolus paru, derajad pada semua kelompok termasuk dalam kriteria berat, dimana kerusakan alveolus paru $>60 \%$ kerusakan maksimal. Hal ini menunjukkan bahwa konsentrasi obat pada reseptor tidak hanya menimbulkan efek terapi, tetapi dapat juga menimbulkan efek toksik. ${ }^{14}$ Walaupun demikian masih diperlukan studi lebih lanjut mengenai suplementasi buah kersen dengan populasi yang lebih besar untuk menilai peran antioksidan buah kersen terhadap perubahan fungsi paru pada perokok.

\section{Simpulan}

Pemberian ekstrak buah kersen tidak berpengaruh terhadap gambaran histopatologi paru tikus yang di papar asap rokok.

\section{Daftar Pustaka}

1. World Health Organization. Global Alliance against Chronic Respiratory Diseases (GARD). Geneva: WHO; 2008.

2. Global Initiative for Chronic Obstructive Lung Disease [homepage on the Internet. Bethesda: GOLD [cited 2012 Dec 10]. Global Strategy for the Diagnosis, Management and Prevention of PPOK---Revised, 2011. Available from: http://www.goldPPOK.org/

3. de Faria CA, de las Heras Kozma R, Stessuk T, Ribeiro- Paes JT. Experimental basis and new insights for cell therapy in Chronic Obstructive Pulmonary Disease. Stem Cell Rev. 2012;8(4):1236-44.

4. Ribeiro-Paes JT, Stessuk T, de las Heras Kozma R. Cell Therapy in Chronic Obstructive Pulmonary Disease: State of the Art and Perspectives. In: Ong KC, editor. Chronic Obstructive Pulmonary Disease - Current Concepts and Practice. Rijeka: InTech; 2012.

5. Muhammad I. Efek Antioksidan Vitamin C Terhadap Tikus )Rattus 
norvegicus L) Jantan Akibat Pemaparan Aasap Rokok. Tesis. Bandung. 2009.

6. Diken H, Kelle M, Tomer C, Denuz B, Baylan Y, Permet A. Effects of Cigarrete Smoking on Blood Antioxidant Status in Short-term and Long-term Smokers. Turk J Med Sci. 2001 (31)553-557.

7. Drath DB,Karnovsky ML, Huber GL. Tobacco smoke. Effects on Pulmonary host defense inflammation.USA. 1979;3(3):281

8. Rima A, Suradi, Surjanto E dan Yunus F. Korelasi antara jumlah makrofa, neutrofil dan kadar enzim matrix metalloproteinase (MMP)-9 Pada cairan kurasan Bronkial perokok. Surakarta. J Respir Indo. 2007.

9. Crystal, RG., 1991. Biologi of Free Radicals, Introduction. Am J Med, 91:15.

10. Noguci $\mathrm{N}$ and Niki E., 1999. Chemistry of Active Oxygen Species and Antioxidationts in Antioxidant Status, diet, Nutrition, nad Health. Edited by Papas AM. CRC Press. New York.

11. Gomathi R, Anusuya $\mathrm{N}$ and Manian S.
A
Dietary
Antioxidant

Supplementation of Jamaican Cherries (Muntingia Calabura L) Attenuates Inflammatory Related Disorders. Food Sci.Biotechnol. 2013.

12. World Health Organization Regional Office for The Western Pacific. Research guidelines for evaluating the safety and efficacy of herbal medicines. The World Health Organization Regional Office for the Western Manila.; 1993.35

13. Hansel T.T. dan Barnes P.J. An Atlas of Chronic Obstructive Pulmonary Disease. London: Parthenon Publishing Group. 2004.pp: 22-36

14. Mycek Mj, Harvey RA, Champe PC. Farmakologi Ulasan Bergambar. 2nd ed.Jakarta: Widya Medika;2001.p21.

15. Prior, R. Fruits and Vegetables in The Prevention of Cellular Oxidative Damage.' Arkansas. Am. J. Clin. Nutr. Vol 78 2003. : 570S-8S.

16. Kormin, S. The effect of Heat Processing on Triterpene Glycosides and Antioxidant Activity of Herbal Pegaga (Centella Asiatica L. Urban) Drink. (Tesis). Kuala Lumpur : Universiti Teknologi Malaysia.2005. 